\title{
La traducción de culturemas en Iván Turguéniev: el método de análisis culturo-traductológico
}

\author{
Enrique J. Vercher García \\ Universidad Complutense de Madrid \\ Plaza Menéndez Pelayo, s/n \\ 28040 Madrid \\ evercher@ucm.es \\ ORCID: 0000-0002-3263-6199
}

\section{Resumen}

En la primera parte del presente artículo se estudia la naturaleza de los denominados culturemas, entendidos como unidades semióticas cuyo referente es un elemento perteneciente a una cultura dada desconocido o sin equivalente exacto en otras culturas y que, por tanto, es percibido como una especificidad cultural. Igualmente, se analizan los criterios tanto para su clasificación por contenido referencial como para su clasificación por relevancia semiótica en una traducción. En la segunda parte se aplica el método culturo-traductológico para analizar culturemas presentes en la obra de Iván Turguéniev Rudin y la forma de transponerlos en las diferentes versiones al español existentes por parte de distintos traductores.

Palabras clave: traductología; culturología; culturema; método culturo-traductológico; Iván Turguéniev; Rudin; lengua rusa; lengua española

Abstract. The translation of culturemes in Ivan Turgenev: The cultural-traductological method of analysis

In the first part of this article, the nature of so-called culturemes is studied, understood as semiotic units referring to an element belonging to a given culture which is unknown or without an exact equivalent in other cultures, and which is therefore perceived as a cultural specificity. Additionally, criteria are examined for both their traditional classification by referential content, and their classification by semiotic relevance in a translation. In the second part, the culturaltraductological method is used to analyse culturemes present in Rudin, the work by Iván Turguéniev, and the way of transposing these in the different Spanish versions by different translators.

Keywords: traductology; culturology; cultureme; cultural-traductological method; Iván Turguéniev; Rudin; Russian language; Spanish language 


\section{Sumario}

1. Introducción. Cultura y traducción. Definición y clasificación de los culturemas

2. El análisis culturo-traductológico de los culturemas como procedimiento teórico-práctico

3. Iván Turguéniev: pensamiento, obra y circunstancias históricas
4. Análisis descriptivo y comparación de culturemas rusos presentes en la obra de Turguéniev en las traducciones a la lengua española

5. Conclusiones

Ediciones y traducciones de obras de Turguéniev empleadas

Referencias bibliográficas

\section{Introducción. Cultura y traducción. Definición y clasificación de los culturemas}

El objetivo de nuestro artículo es profundizar en la noción de especificidad cultural y en sus unidades semióticas, los culturemas, analizar y describir algunos ejemplos de culturemas presentes en distintas obras del escritor ruso Iván Serguéyevich Turguéniev y llevar a cabo un análisis descriptivo-comparativo de las distintas soluciones traductológicas escogidas por diferentes traductores en sus versiones españolas de las obras analizadas.

Uno de los campos más fructíferos dentro de las investigaciones traductológicas es el del análisis de la traducción de los elementos culturales. Cuando un elemento cultural de una sociedad dada es desconocido o sin equivalente en otra cultura, se habla de especificidad cultural.

Ahora bien, lo cierto es que no existe unanimidad a la hora de entender el concepto de cultura ni de establecer el número y tipología de culturas existentes. Cultura (del lat. colere) a partir del s. XVIII se entiende como todo aquello que existe como resultado de la actividad del hombre y de sus reflexiones. Según el DRAE, cultura en su segunda acepción sería 'Conjunto de modos de vida y costumbres, conocimientos y grado de desarrollo artístico, científico, industrial, en una época, grupo social, etc. '. ${ }^{1}$ Son muy numerosas las definiciones que los distintos autores han dado al concepto de cultura. K. Reiss y H. J. Vermeer, por ejemplo, lo entienden como «el conjunto de las normas y convenciones vigentes en una sociedad, así como todos los comportamientos a que éstas dan lugar y los productos resultantes de dichos comportamientos» (Reiss y Vermeer 1996: 20).

A la hora de establecer una tipología y número de culturas, deberemos tener en cuenta varios posibles niveles de afinidad de los componentes de una cultura. Así, en un primer nivel podríamos distinguir los diferentes grandes tipos cultural-

1. Término muy cercano sería el de civilización (del latín civilis), que aparece en el siglo XVII como lo opuesto a lo salvaje. Desde finales del s. XIX surge en Alemania un nuevo sentido para civilización, entendida como el conjunto de bienes materiales y sociales de una sociedad gracias al desarrollo en su producción. Cultura se entendía entonces como contenido espiritual de la civilización (Maslova 2001 (2004): 20-21). 
históricos (término tomado de N. Danilevski, precursor de la idea de las grandes culturas de O. Spengler), es decir, la egipcia, la china, la india..., con las variaciones encontradas en función del autor (así por ejemplo, Danilevski distingue la cultura eslava como un gran tipo cultura-histórico diferenciado de otros, por lo que ya incluso en este primer gran nivel encontramos falta de unanimidad al establecer las culturas que hay). En un siguiente nivel encontraríamos las culturas nacionales (la rusa, la española, la alemana, la china, etc.), y que es el que se suele tener en cuenta (de manera más o menos consciente y explícita) en los estudios de traductología, pero también con la falta de unanimidad a la hora de establecer los criterios de composición de cada cultura nacional y, por tanto, el número existente de estas culturas nacionales, problema relacionado con el siguiente nivel de tipología cultural por afinidad de sus componentes: las culturas regionales, sociológicas, ideológicas o de otras índoles.

El desarrollo del estudio de los elementos culturales o de las especificidades culturales en traducción ha ido evolucionando desde los ámbitos culturales de Nida o las palabras culturales de Newmark a los indicadores culturales de Nord o conceptos como los de realia o culturema, concepto este último en el que nos basaremos para nuestro trabajo.

El término culturema fue introducido por primera vez en 1976 por Fernando Poyatos en su obra Man beyond Words (no procede originariamente de Els Oksaar, como a veces suele pensarse, sino que esta lo tomó de Poyatos). Para Poyatos el culturema haría referencia a ciertos comportamientos culturales en ciertas situaciones recurrentes que varían según los factores culturales, verbales, no verbales y extraverbales. El término fue retomado y desarrollado por otros teóricos como Vermeer, Oksaar, Nord, Gak, Vezhbitskaya, Vorob’ëv, Pamies o Luque Nadal.

Del término culturema existen diversas definiciones que llegan a diferir sustancialmente entre sí. ${ }^{2}$ Nosotros nos vamos a basar en su concepción de unidad semiótica cuyo referente es un elemento material o inmaterial (herramientas, utensilios, vestimenta, ornamentos, costumbres, instituciones, creencias, rituales, juegos, etc.) existente en una cultura dada y desconocido o sin equivalente exacto en otras culturas y, por tanto, percibido como una especificidad cultural.

El término aplicado a la teoría de la traducción abarcaría, por tanto, todo tipo de unidades del plano de la expresión (palabras, oraciones, fragmentos, descripción de situaciones, alusiones, etc.) referidas a realidades o contextos históricosociales presentes en el texto original, conocidas y captadas en la lectura por el receptor del original, pero de difícil transmisión al receptor de otra cultura. Ahora bien, los culturemas pueden materializarse verbalmente en el texto de partida (así

2. Para una compilación y resumen de las distintas concepciones y definiciones que se han dado sobre culturema y otros términos afines, véase Soto Almela (2013), quien acaba concluyendo que «vistas las distintas definiciones, podemos concluir que los culturemas son términos de índole cultural, pertenecientes a ámbitos diferentes de una misma cultura, conocidos y compartidos por todos los miembros de una sociedad que, al ser transferidos a otra cultura, pueden dar lugar a problemas traductológicos, lo que supondrá una posible adaptación lingüística del término por medio de diversas técnicas de traducción para hacerlo comprensible en la cultura receptora». 
ocurriría con los juegos de palabras, léxico sin equivalente o con las singularidades gramaticales directamente relacionadas con la visión del mundo de los hablantes) o pueden estar implícitos en el conocimiento que de su propia sociedad y cultura tiene el receptor nativo (gestos, costumbres, referencias culturales).

Los culturemas se caracterizan, en primer lugar, por la intersemiosis, entendida aquí como la característica del culturema de expresarse verbalmente o no (connotaciones, datos culturales o históricos compartidos por los hablantes de una cultura dada, gestos, costumbres...). Otro rasgo distintivo sería la contextualidad, es decir, que los culturemas no son entes abstractos teóricos e inamovibles, sino que se materializan en un con(texto) dado, están vivos y pueden sufrir variaciones, aparecer y desaparecer como tales culturemas (por ejemplo, el fútbol pasó de ser un culturema inglés a ser algo prácticamente universal cuando dejó de ser una especificidad cultural de aquel país y se extendió por otros países).

Los culturemas son, por tanto, un grupo abierto tanto temporalmente como espacialmente. A lo largo del tiempo aparecen y desaparecen en una sociedad dada las especificidades culturales que los motivan (los culturemas que un hablante extranjero deba conocer para entender plenamente un texto no serán los mismos si estamos hablando del español del Siglo de Oro que del español actual). No existen fuera de contexto ni ajenos a una relación o transversalidad entre dos culturas (un mismo elemento puede ser un culturema entre dos lenguas concretas y no serlo entre otras dos lenguas con mayor afinidad cultural).

Los culturemas han recibido también diversas clasificaciones en función del criterio utilizado. Una de las primeras y más conocidas es la que realizara E. A. Nida (1945), quien estableció cinco grupos de problemas de traducción (problemas de equivalencia) por su información cultural: 1. Ecología (los que surgen por las diferencias naturales, climatológicas, de flora, fauna... entre los hábitats de dos culturas); 2. Cultura material (herramientas, utensilios y objetos propios de una cultura); 3. Cultura social (aquí incluye diferencias entre la organización social y familiar de dos culturas y su reflejo en la lengua —él cita como ejemplo la ausencia de una palabra genérica para hermano y hermana en la lengua maya); 4. Cultura religiosa (se refiere a la dificultad de trasladar de una cultura a otra conceptos como los de santidad, sagrado, espíritu, adivinación o títulos y nombres de divinidades); y 5. Cultura lingüística (dificultades de traducción derivadas de características lingüísticas propias de la lengua de una cultura dada).

Esta clasificación fue retomada con algunas modificaciones por P. Newmark (1988), quien distingue las siguientes categorías culturales: 1. Ecología; 2. Cultura material; 3. Cultura social; 4. Organizaciones, costumbres, actividades, procedimientos, conceptos; 5 . Gestos y hábitos.

Otras clasificaciones destacables han sido las de Nord (1994): 1. ambiente natural; 2. modo de vivir; 3. historia; 4. patrimonio cultural. Katan (1999): 1. entorno; 2. conducta; 3. capacidades, estrategias y habilidades para comunicarse; 4. valores; 5. creencias; 6. Identidad. Molina Martínez (2001): 1. medio natural; 2. patrimonio cultural; 3. cultura social; 4. cultura lingüística. Jaskot y Ganoshenko (2015): 1. Culturemas-realia o culturemas nominativos, con varios subgrupos en función del campo semántico: 1.1 vida pública/social, 1.2 arte, 
1.3 vida cotidiana o rutina, 1.4 geografía y meteorología, 1.5 religión; 2. Culturemas denotativos; 3. Culturemas significativos; 4. Culturemas connotativos; 5. Culturemas de imagen.

En nuestra opinión, los grupos de las distintas clasificaciones de los culturemas basadas en el campo semántico cultural del referente podrían reducirse a tres grandes categorías, tal como hizo R. Bierstedt (1970: 135 y ss.) en su clasificación del contenido de la cultura: 1. ideas o lo que pensamos (ideas [thinking]): verdades científicas, creencias religiosas, mitos, leyendas, literatura, supersticiones, aforismos, proverbios y folklore; 2. normas o lo que hacemos (norms [doing]): leyes, estatutos, reglas, regulaciones, hábitos, tradiciones, costumbres, tabúes, moda, ritos, rituales, ceremonias, convenciones y etiqueta; y 3. material o lo que tenemos (materiel [having]): máquinas, herramientas, utensilios, edificios, carreteras, puentes, artefactos, obras de arte, ropa, vehículos, mobiliario, alimentos, medicinas. Retomaremos y profundizaremos en esta clasificación en el apartado en que analizamos culturemas presentes en la obra de Turguéniev.

Los culturemas también han sido analizados y clasificados en base a otros criterios. Por su verbalización, pueden ser verbales o no verbales; por su estructura, pueden ser simples o complejos; por su valor diacrónico, pueden ser arcaicos o actuales; por su variedad diatópica, pueden ser comunes a toda una cultura o regionales; por su variedad diafásica (o función estilística), pueden ser formales, coloquiales, jergales, etc. (cf. Nicolae 2015).

En nuestro trabajo planteamos otro criterio más de clasificación de los culturemas especialmente relevante para el campo de la traductología, pero que, en cualquier caso, no excluye otras posibles clasificaciones que acabamos de citar. Nos referimos al criterio de la relevancia semiótica de un culturema dado en la comprensión de un texto y, por tanto, su relevancia a la hora de ser trasladado a la lengua meta. De este modo, podemos distinguir culturemas de relevancia semiótica alta, media o baja.

Por relevancia semiótica alta entendemos la que posee un culturema dado imprescindible para la comprensión de un texto. Se trata habitualmente de culturemas que constituyen uno de los elementos centrales en torno al que gira un texto, y a veces aparecen en el título mismo de la obra. Sería el caso de jor ('hurón') en la historia de Jor y Kalinich de Memorias de un cazador de Turguéniev.

Por relevancia semiótica media entendemos la de todo aquel culturema que, sin ser un concepto central en la obra, es de gran importancia para la plena comprensión del texto. Sería el caso del carácter simbólico y polisémico que tiene el apellido Raskólnikov, protagonista de Crimen y castigo, para el nativo ruso, ya que procedería de la palabra раскол [raskol] con una doble acepción: por un lado, alude а раздвоение [razdvoienie] ('desdoblamiento' — de la personalidad, por ejemplo) у por otro а раскольничество [raskolnichestvo] ('cisma'). ${ }^{3}$

Por relevancia semiótica baja entendemos la de aquellos culturemas de un texto dado cuyo desconocimiento por parte del receptor no afecta significativa-

3. Por ejemplo, a los denominados viejos creyentes que no aceptaron las reformas de Nikon (s. XVII) se los denomina también raskólniki. 
mente a la comprensión general del texto (aunque pueda suponer la pérdida de ciertas connotaciones menores o de cierto colorido cultural). ${ }^{4}$ Sería el caso de lezhanka, armiak, izba... en la obra Rudin de Turguéniev.

El grado de relevancia semiótica de un culturema no es un valor intrínseco del mismo, sino que dicha relevancia vendrá determinada por el (con)texto concreto en que aparezca. Sería el caso, por ejemplo, de samovar, que puede tener una relevancia semiótica baja, media o incluso alta, como ocurriría en el relato $L a$ familia del samovar de S. G. Pisajov. El culturema debe entenderse, por tanto, como un concepto vivo, abierto y fuertemente contextualizado. El culturema chaman, por ejemplo, sería de relevancia semiótica alta en la obra Chamán de Siberia, pero podría tener otro grado de relevancia en otros contextos.

\section{El análisis culturo-traductológico de los culturemas como procedimiento teórico-práctico}

En el presente trabajo nos proponemos establecer un procedimiento de análisis de culturemas y de su traducción a otras lenguas que sistematice la aplicación de los distintos conceptos teóricos desarrollados por diversos autores del campo de la culturología y la traductología.

El punto de partida es la idea de que para analizar correctamente y en toda su profundidad el modo en que se ha vertido a otra lengua un culturema dado es necesario llevar a cabo una doble línea de análisis, una propiamente traductológica, por un lado, y otra de exégesis cultural y literaria del original, por otro. Es por ello por lo que denominamos al tipo de análisis aquí estudiado análisis culturo-traductológico.

Un primer concepto esencial en el procedimiento de un análisis culturo-traductológico es el de skopos. Skopos ${ }^{5}$ ('objetivo') es el concepto central de la Teoría del Skopos, que tiene su origen en N. Chomsky y E. A. Nida, y que luego fue desarrollada por la Escuela de Saarbrücken (Wilss) y por la Escuela de Leipzig (Kade, Neubert, Wotjak, Jäger, Helbig, Ruzicka). La finalidad para la que se realiza una traducción condicionará radicalmente la naturaleza y estrategias de la misma. En otras palabras, podrá haber tantas traducciones posibles como objetivos se plantee el traductor. El skopos va a determinar la invariable traductora, ${ }^{6}$ el

4. Por ejemplo, el culturema kvas, en su sentido literal una bebida fermentada hecha a base de pan de centeno o de harina y malta, típica de Rusia y de otros países de Europa central y oriental, pero empleado con las connotaciones de ser un ruso auténtico castizo, un hombre del pueblo, en el siguiente fragmento de Rudin:

Incluso Pigasov callaba, y como Darya Mijailovna le hiciera observar lo poco simpático que resultaba aquel día, contestóle malhumorado:

— ¿Es que alguna vez fui simpático? Ese no es mi fuerte... —Y con amarga sonrisilla, añadió-: Tenga un poco de paciencia. Porque yo soy kvas, kvas, ruso auténtico..., pero su kamer-junker...

5. También se ha empleado en la bibliografía en castellano la forma escopo (vid. Reiss y Vermeer 1996).

6. Es decir, la naturaleza de la relación entre la traducción y el original, en qué modo se han trasladado a la lengua meta forma y contenido, cómo se ha entendido y reformulado el sentido (más allá del significado y de la designación, en terminología de Coseriu (1977)). 
método traductor ${ }^{7}$ y la estrategia de traducción. ${ }^{8}$ El skopos influirá también en la forma de superar los problemas de traducción (lingüísticos, extralingüísticos, instrumentales y pragmáticos) y en la elección de técnicas de traducción. ${ }^{9}$ Así por ejemplo, una traducción filológica tenderá a incluir mayor cantidad de dobletes, descripciones, amplificación o notas a pie de página; la traducción de un texto perteneciente a una cultura más lejana o menos conocida por el receptor (por ejemplo, parece evidente que en el mundo hispano es más conocida la cultura anglosajona que la rusa) admitirá más adaptaciones, ampliaciones lingüísticas, amplificaciones, compensaciones...; y así un largo etcétera que dependerá de la naturaleza del original y del skopos de la traducción.

A su vez, conocer el método y las estrategias traductoras seguidos por el traductor puede ser determinante en el análisis culturo-traductológico de culturemas y, además, nos servirá para entender mejor la elección de técnicas de traducción por las que se ha decantado el traductor.

Otro concepto esencial en el procedimiento de un análisis culturo-traductológico es el de equivalencia dinámica. Es decir, frente a la mera equivalencia en sus sentidos más antiguos de correspondencia lingüística o de condición en una traducción para ser reconocida como válida (vid. J. P. Vinay y J. Darbelnet (1958); E. A. Nida (1959); J. C. Catford (1965), la equivalencia dinámica parte de la idea de la imposibilidad de la equivalencia lingüística absoluta y tiene como

7. La dicotomía tradicional del método traductor ha sido la de traducción literal vs traducción libre, pero actualmente esta dicotomía tradicional se ha superado y se han planteado nuevas concepciones y clasificaciones del método traductor. Así, por ejemplo, Hurtado Albir (2004), teniendo en cuenta los objetivos del traductor, el proceso traductor desarrollado y el contexto sociohistórico, distingue entre método interpretativo-comunicativo, método literal, método libre y método filológico. Desde esta perspectiva, los autores que se enmarcan en la Teoría del Skopos proponen varios métodos de traducción en función del skopos: la traducción interlineal (palabra por palabra), la traducción literal (al pie de la letra, pero respetando la sintaxis de la lengua de llegada), la traducción filológica (traducción que respetaría la sintaxis, semántica y pragmática de la lengua de llegada), la traducción comunicativa (aquella en la que se transmite sobre todo la información, adaptando el lenguaje, expresiones, etc., a la lengua de llegada) y la traducción creativa (cuando el traductor se ve obligado a crear términos y conceptos que no existen en la lengua de llegada).

8. Es decir, los «procedimientos individuales, conscientes y no conscientes, verbales y no verbales, internos (cognitivos) y externos utilizados por el traductor para resolver los problemas encontrados en el proceso traductor y mejorar su eficacia en función de sus necesidades específicas» (Hurtado Albir 2004: 276). Un tema muy debatido en la cuestión de las estrategias de traducción es la forma en que deben traducirse nombres propios, cargos, unidades de medida, etc. Por ejemplo, Rafael Cansinos Assens en sus traducciones muchas veces mantiene la forma original rusa de nombres de ciudades; así en su traducción de Nido de nobles leemos Moskva, Peterburg... El traductor anónimo de la edición de 100 clásicos universales traduce nombres propios Pablo en vez Pavel, Irene en vez de Irina, etc.; además, se percibe la existencia de una lengua mediadora (el francés) en la forma de transcribir algunos apellidos como Orsinine en vez de Orsinin.

9. Por técnica de traducción se entiende el «procedimiento verbal concreto, visible en el resultado de la traducción, para conseguir equivalencias traductoras» (Hurtado Albir 2004: 256-257). Técnicas de traducción serían la adaptación, la amplificación linguíística, el calco, la elisión, el equivalente acuñado, el préstamo, la transcripción, etc. 
principio general que en el receptor nativo de otra lengua se produzca la misma reacción que en el receptor de la lengua del original. El análisis culturo-traductológico de las distintas soluciones escogidas por un traductor revelarán hasta qué punto era factible y hasta qué punto se ha logrado en una traducción provocar en el receptor de la lengua (o cultura) meta la misma reacción que en el de la lengua de partida.

Por otro lado, como apuntábamos anteriormente, el análisis culturo-traductológico de culturemas en una traducción debe incluir todo el aspecto relacionado con la exégesis culturológica (incluida la lingüística) y literaria, lo que abarca la localización, determinación del grado de afinidad a la cultura de llegada, descripción de los mismos y estudio literaturológico (en el caso de obras literarias) de los culturemas.

La localización y confirmación de los culturemas presentes en una obra está muy relacionado con el propio bagaje académico y cultural del investigador. Los culturemas del tipo de sutiles alusiones a costumbres, personajes históricos o literarios, frases hechas, noticias de actualidad, etc., no siempre son fáciles de detectar y reconocer.

Dado el carácter abierto y en constante evolución de los culturemas, según apuntábamos anteriormente, puede haber diferentes grados de afinidad de los mismos en la lengua de partida y en la lengua de llegada. Por un lado, podríamos hablar de afinidad strictu sensu cuando dos culturas son muy cercanas y comparten culturemas en mayor o menor medida. Respecto a esto, debemos señalar que habría que diferenciar entre cultura y lengua. Evidentemente, por regla general lenguas cercanas suelen representar culturas cercanas (así, por ejemplo, ocurre con los pueblos latinos), pero no es una regla estricta, hay casos de culturas cercanas con lenguas tipológicamente distintas y, por el contrario, puede haber culturas que hayan evolucionado de manera muy diferenciada pero que compartan lenguas tipológicamente cercanas. Por otro lado, puede existir, traductológicamente hablando, afinidad cuando, aun tratándose de culturas muy diferentes, la cultura de partida sea bien conocida por los hablantes de la cultura de llegada (esto ocurriría con la cultura anglosajona, y muy especialmente con la estadounidense, ampliamente conocida en otras culturas merced al cine y los medios de comunicación). Un ejemplo curioso de distinto grado de afinidad dentro de un mismo tipo de culturemas sería el de diferentes bebidas tradicionales rusas: en el mayor grado de afinidad estaría el vodka, bebida ya ampliamente conocida y consumida fuera de Rusia; en un grado inferior estaría el kvas, sin duda mucho menos famoso, pero que puede ser conocido por cierta parte de la sociedad española, ya que se vende en establecimientos rusos y porque aparece con cierta frecuencia en obras literarias rusas (incluido en Turguéniev); en un grado de mayor desconocimiento se encontraría el samogon (aguardiente casero fabricado de manera artesanal).

Aunque en el presente trabajo nos centremos en obras literarias, esta cuestión puede afectar a textos de muy diversa índole. Piénsese, por ejemplo, en el estudio que realiza Kocbek (2012) sobre el papel de los culturemas en la traducción de textos legales. Esta autora señala las posibles variantes que puede haber 
entre sistemas legales y las lenguas de los países donde imperan dichos sistemas legales. ${ }^{10}$

Finalmente, la descripción culturológica de los culturemas incluye la búsqueda de información sobre los mismos, donde entran en juego los conocimientos del traductor o, en su caso, del investigador sobre la cultura de partida y de llegada. Un aspecto de esta descripción culturológica sería el análisis literaturológico (fuentes literarias, alusión a citas literarias conocidas por los hablantes de una cultura dada, connotaciones de un personaje literario en esa cultura, etc.).

El procedimiento de análisis culturo-traductológico de culturemas deberá incluir, por tanto, estos seis aspectos o fases:

1. Localización y confirmación de potenciales culturemas;

2. Adscripción a una de las categorías por tipo de referente;

3. Análisis, descripción y búsqueda de información (histórica, social, lingüística, cultural...) del culturema;

4. Determinación de su grado de afinidad con la cultura de llegada;

5. Determinación de su relevancia semiótica en la traducción a otros idiomas;

6. Descripción y análisis de las soluciones traductológicas escogidas por los traductores en base a la equivalencia dinámica y a otros principios traductológicos señalados (skopos, método traductor, estrategias traductoras, problemas de traducción, etc.).

Antes de pasar a aplicar de manera práctica este procedimiento en el caso de culturemas presentes en la obra de Turguéniev, vemos necesario recoger algunos de los aspectos más importantes de su vida, pensamiento, obra y circunstancias históricas.

\section{Iván Turguéniev: pensamiento, obra y circunstancias históricas}

No es lugar este para exponer de manera extensa el pensamiento de Turguéniev ni las características sociales, culturales e históricas que le tocó vivir, pero sí creemos necesario dar algunas pinceladas sobre los rasgos más importantes de estos aspectos para entender los culturemas presentes en sus escritos y, por tanto, los posibles problemas traductológicos a la hora de trasladarlos a otra lengua.

Iván Serguéyevich Turguéniev (1818-1883) nació en el seno de una acaudalada familia de terratenientes y durante su infancia ejercería gran influencia en su personalidad su autoritaria madre. Estudió filología en Moscú y San Petersburgo, pero especial relevancia en su obra y pensamiento tuvo el periodo en que vivió y estudio filosofía en Berlín. En San Petersburgo conocería a la cantante española Paulina García de Viardot, con quien mantendría un idilio y por quien marcharía a

10. De este modo, ella habla de sistemas legales similares presentes en países con lenguas cercanas (España y Francia, por ejemplo), de sistemas legales similares, pero en países de lenguas distintas (Países Bajos y Francia), de sistemas legales muy diferentes, pero entre lenguas cercanas (Alemania y Países Bajos -neerlandés) y de aquellos casos en que tanto los sistemas legales como las lenguas son distintos (Reino Unido y Eslovenia). 
París, pasando la mayor parte del resto de su vida entre Baden-Baden y París (ciudades muy presentes en su obra). También visitaría ocasionalmente Inglaterra (la Universidad de Oxford le concedió el título honorífico de doctor en Derecho Civil).

Un aspecto central del pensamiento de Turguéniev (como podemos comprobar, muy relacionado con su propia biografía) es su occidentalismo. Los occidentalistas, la mayoría de ellos miembros de la nobleza terrateniente, advertían el retraso político y cultural de Rusia en relación con Occidente y la necesidad de remediarlo. A grandes rasgos defendían que el desarrollo de Rusia debería seguir el modelo occidental, la abolición del régimen de servidumbre, defendían los sistemas constitucionales y parlamentarios de Occidente, el desarrollo de la industria, el comercio y las comunicaciones. Algunos occidentalistas, como Belinski, llegaron a abogar por la abolición de la monarquía. Para los occidentalistas el aspecto político era esencial. El apoyo al pensamiento ilustrado occidental, la crítica a la autocracia rusa, los derechos del individuo, como la libertad y la dignidad, y la relativización de la importancia de las raíces históricas y nacionales rusas eran conceptos centrales entre ellos. En ese Occidente del que hablamos, por cierto, España ocuparía un lugar no menor para Turguéniev. Su amor por la cultura española daría lugar a su ensayo Hamlet y Don Quijote, obra esta última que cita literalmente en Rudin y que siempre soñó traducir al ruso sin llegar a realizarlo.

A los occidentalistas se opondrían, en cierto modo, los denominados eslavófilos, quienes van a defender la identidad cultural rusa, la idea de que Rusia poseía una espiritualidad sui generis y debía seguir por ello su propio camino histórico, la hegemonía de Rusia sobre el resto de Europa, la idea de que la cultura rusa era equiparable en importancia a la de cualquier otro pueblo europeo, y el convencimiento de que Rusia salvaría a la decadente Europa o incluso que desplazaría o destruiría Europa (Catalina II había llegado a decir «si mi reinado durara doscientos años, toda Europa quedaría sometida a la Corona de Rusia»).

No obstante, tanto occidentalistas como eslavófilos coinciden en la idea de que en Rusia hay una excesiva pobreza y la necesidad de mejoras. Esta visión negativa generalizada se eleva, por tanto, a categoría de culturema presente en el subconsciente de la mayoría de los autores rusos del s. XIX.

Lo dicho no es incompatible con encontrar también en Turguéniev un cierto desencanto por el excesivo positivismo de su época llegado de Occidente y por el nihilismo (término que introduce precisamente él), así como un rechazo a ciertos aspectos del pensamiento revolucionario occidental (por ejemplo, la visión negativa de los campesinos, que tiene su origen en el propio pensamiento de Karl Marx). En general, se percibe un tono pesimista en su obra causado por sus experiencias vitales e históricas.

De la época en que vivió Turguéniev y en la que transcurre la acción de la mayoría de sus obras (s. XIX) podemos destacar la autocracia con un poder casi omnímodo del zar y la persecución de cualquier reforma liberal y democrática (con algunas excepciones puntuales, por ejemplo las realizadas por Alejandro II), la férrea censura o la existencia hasta 1861 del régimen de servidumbre (se podían comprar y vender campesinos adscritos a tierras, infligirles castigos físicos...), pero también los diversos movimientos que de un modo a otro se van a 
oponer a esta realidad político-social, como la de los decembristas y liberales, los nihilistas, los populistas (narodniki) y social-revolucionarios, los anarquistas y los socialistas.

Para entender la época que estamos estudiando es necesario conocer algunos conceptos como puedan ser la tradicional idea de «Moscú tercera Roma» (Rusia, como legítima heredera y representante tanto del Imperium - y su correspondiente poder político-, como de la auténtica Iglesia Cristiana - la Iglesia Ortodoxa Rusa-, tras la caída de Roma y Bizancio), el paneslavismo (la unión política y espiritual de todos los eslavos, defendido, entre otros, por Danilevski), el bizantinismo (unión de los ortodoxos, con la civilización bizantina como guía, ideal defendido, por ejemplo, por Leóntiev), o la denominada filosofía cristiana de Soloviov (y su idea central del ecumenismo universal), pero también la introducción en Rusia de la Ilustración, el positivismo y el materialismo. En definitiva, la dualidad como un rasgo caracterizador de Rusia y esencial para entender su cultura (y presente, por tanto, en los culturemas que vamos a analizar).

Cabe mencionar aquí por su relevancia lingüística y cultural, la importancia de la lengua francesa y su extendido uso, especialmente entre las clases altas, de la Rusia de los ss. XVIII y XIX. Este hecho está muy presente en la literatura rusa (Guerra y paz está escrita en gran parte en francés en el original); valga el siguiente pasaje de Nido de nobles de Turguéniev de ejemplo ilustrativo:

Vladimir Nikolaich hablaba el francés a la perfección, bastante bien el inglés y mal el alemán. Así tiene que ser; las personas distinguidas tienen a menos hablar bien el alemán; pero sí está bien mirado entre ellas el poder soltar en la conversación alguna que otra palabreja germánica en algunos casos, generalmente es en broma y estiman que c'est même très chic, como dicen los parisienses de Peterburg. (trad. de Rafael Cansinos Assens; Turguéniev 1951: 159)

En general, conviven en la Rusia del XIX el estilo de vida (y esto incluye costumbres, bienes materiales, forma de hablar, referencias culturales, etc.) más tradicional ruso, presente sobre todo en los campesinos y clases populares, por un lado, y el estilo de vida occidentalizante, sobre todo afrancesado, más propio de la nobleza (también la pequeña nobleza, no solo la alta aristocracia). Este hecho está ampliamente representado en la literatura rusa de la época.

\section{Análisis descriptivo y comparación de culturemas rusos presentes en la obra de Turguéniev en las traducciones a la lengua española}

Pasamos a continuación a aplicar el procedimiento propuesto en el caso de culturemas presentes en obras de Iván Turguéniev. Por la naturaleza de este trabajo nos centraremos en los culturemas más representativos de Turguéniev o en aquellos que puedan ilustrar mejor la aplicación del análisis culturo-traductológico.

Nosotros vamos a clasificar los culturemas analizados en los tres grandes grupos que apuntábamos anteriormente basados en los tres tipos de contenido cultural de Bierstedt: ideas, normas y cultura material. 


\subsection{Culturemas pertenecientes al campo de las ideas}

Este primer gran grupo en la clasificación por contenido cultural que seguimos representa todas aquellas especificidades culturales no materiales surgidas como resultado del pensamiento y el razonamiento humano. Como indicábamos anteriormente, nos referiríamos a las verdades científicas, creencias religiosas, mitos, leyendas, supersticiones, etc. ${ }^{11}$

Dentro de este grupo incluiríamos también aquellos culturemas pertenecientes al campo de la lengua y la literatura de una cultura dada. Hablamos, por tanto, de linguoculturemas o peculiaridades lingüísticas (fonético-fonológicas, morfológicas, léxicas, sintácticas, supraoracionales, visión lingüística del mundo), refranes, frases hechas, juegos de palabras, etc., así como de obras y personajes literarios conocidos por una sociedad dada y que sirvan como referente simbólico de una idea o acontecimiento, citas literarias y frases hechas con un origen literario, etc.

Así pues, este primer gran grupo vendría a incluir la cultura religiosa y la cultura lingüística de Nida, los conceptos de Newmark, el patrimonio cultural de Nord, las capacidades, estrategias y habilidades para comunicarse, valores, creencias e identidad de Katan o el patrimonio cultural y la cultura lingüística de Molina Martínez.

En Turguéniev podemos encontrar numerosos ejemplos de culturemas de este tipo. Algunos son culturemas transversales comunes a muchas culturas y, por tanto, con mayor grado de afinidad a la cultura hispana; así, en Rudin se habla de ser un Mecenas, un Tartufo, de ser los últimos mohicanos, etc. Otros culturemas son más específicos de la cultura rusa, como la alusión en Rudin al personaje literario de Repetilov de El mal de la razón de Griboyédov en forma de cita del verso «О честности высокой говорит...» [o chestnosti vysokoj govorit...] ('Cuando del perfecto honor / entusiasmado nos habla') para referirse a Lezhnev. Se usa en este caso como comentario irónico para referirse a una persona deshonesta o con unos principios morales cínicos. El grado de afinidad a la lengua de llegada es bajo, por cuanto el lector español no suele conocer esta alusión, aun cuando por el contexto del pasaje pueda entenderlo. La relevancia semiótica es media, pues aun no siendo esencial para la comprensión de la historia, sí que ayuda a comprender la opinión de Lezhnev sobre Rudin, el protagonista. Los diferentes traductores de esta obra tienen que valerse de distintas técnicas para trasladar este culturema. Así, el traductor de la versión publicada en La España moderna (1893) y la traductora María Rosa Turuguet (1942) añaden una nota a pie de página explicándolo, mientras que Rafael Cansinos Assens o Aníbal Leal no incluyen ninguna explicación de esta referencia cultural.

Otros culturemas de este tipo en Turguienev serían los que encontramos por ejemplo en Rudin: la alusión al personaje literario de Pechorín (que encarna el

11. Bierstedt (1970: 137) pone de ejemplo conceptos como el de que las líneas paralelas en el espacio euclídeo nunca se encuentran o que los cuerpos en el vacío caen a la misma velocidad con independencia de su masa, ideas que no existirían en culturas aborígenes. 
prototipo de hombre taimado que es amado por mujeres aun no mereciéndolo), protagonista de Un héroe de nиеstro tiempo, de Lérmontov; las palabras хохол [hohol] у Хохландия [Hohlandija] (formas humorísticas, irónicas y en cierto grado despectivas de llamar a los ucranianos y a Ucrania); o las imitaciones que hace Pigasov de cómo suena el ucraniano (zpae, гpae вoponae, zon! zon! igrae, grae voropae, gop! igop!).

En Padres e hijos tendríamos ejemplos como los siguientes: el apodo Burdalú, que se le daba a un gobernador apellidado en realidad Bourdaloue (juego de palabras con la palabra rusa burdá 'aguachirle, brebaje, bebida insulsa o mal preparada'); el juego de palabras irónico que hace Bazarov con la palabra mir (por su polisemia, ya que puede significar 'comunidad rural de campesinos' además de 'mundo', entre otros posibles significados); el proverbio ruso не боги горики обжигают [ne bogi gorshki obzhigajut] sin equivalente exacto (traducido por J. Fernández-Valdés como ‘EEl trabajo sucio no es para los dioses!', otros traductores lo traducen de manera más o menos acertada); la expresión кmo cmapoe помянет, тому глаз вон [kto staroe pomjanet, tomu glaz von]. ${ }^{12}$

O finalmente el рубашка-парень [rubashka-paren'] (literalmente 'camisamuchacho', pero con el sentido de 'buen muchacho, sin maldad') o el с умом цыллленка [s umom tsyplionka] ('poco inteligente', literalmente 'con la inteligencia de un pollo') de Нито; el он ручки у тебя всё лижет [on ruchki u tebja vsio lizhet] ('te hace la pelota', literalmente 'te lame todo las manitas') de Nido de nobles; о el одначе [odnache] ('sin embargo', dialectismo para caracterizar a un personaje) de Memorias de un cazador serían otros ejemplos de culturemas del campo de las ideas, las creencias y las particularidades lingüísticas de la cultura rusa.

En el apartado anterior hablamos del debate entre eslavófilos y occidentalistas que ocupó gran parte del s. XIX y que es una cuestión central para entender el pensamiento, la política y el arte del s. XIX ruso (y en cierto modo todavía continúa). La forma en que se dio este debate en Rusia es bastante específica y puede constituir, por tanto, un culturema de este primer gran grupo del que estamos hablando. Conocerlo es imprescindible para entender pasajes como el siguiente de Humo de Turguéniev:

- C чем вас поздравляю. Нет, я терпелив. Но «возвратимся на первое», как говорит почтенный мой собрат, сожженный протопоп Аввакум. Удивляюсь я, милостивый государь, своим соотечественникам. Все унывают, все повесивши нос ходят, и в то же время все исполнены надеждой и чуть что, так на стену и лезут. Вот хоть бы славянофилы, к которым г-н Губарев себя причисляет: прекраснейшие люди, а та же смесь отчаяния и задора, тоже живут буквой «буки». Всё, мол, будет, будет. В наличности ничего нет, и Русь в целые десять веков ничего своего не выработала, ни в управлении, ни в суде,

12. J. E. Zúñiga y B. Martinova la traducen por el equivalente acuñado español «agua pasada no mueve molino», mientras que R. Cansinos Assens opta por traducir como «no hay que acordarse de lo pasado», R. Cañete Fuillerat «olvidemos el pasado» y J. Fernández-Valdés «lo pasado pasado está». 
ни в науке, ни в искусстве, ни даже в ремесле... Но постойте, потерпите: всё будет. А почему будет, позвольте полюбопытствовать? А потому, что мы, мол, образованные люди,- дрянь; но народ... о, это великий народ! Видите этот армяк? вот откуда всё пойдет. Все другие идолы разрушены; будемте же верить в армяк. Ну, а коли армяк выдаст? Нет, он не выдаст, прочтите Кохановскую, и очи в потолоки! [...].

- После того, что вы сейчас сказали,- промолвил с улыбкой Литвинов,- мне нечего и спрашивать, к какой вы принадлежите партии и какого мнения вы о Европе. Но позвольте мне сделать вам одно замечание. Вот вы говорите, что нам следует занимать, перенимать у наших старших братьев; но как же возможно перенимать, не соображаясь с условиями климата, почвы, с местными, с народными особенностями? (Тургенев 1978-2014 [1981]: 272-273).

El fragmento reproduce una conversación entre Litvínov y Potugin. La traducción del mismo al español realizada por Víctor Gallego Ballestero reza así:

-Pues le felicito por ello. No, soy un hombre paciente. Pero «volvamos al principio», como decía mi respetable cofrade, el protopope Avakum, que fue quemado vivo. Mis compatriotas me sorprenden, querido amigo. Todos se lamentan, todos andan cabizbajos y al mismo tiempo todos están llenos de esperanza y a la menor oportunidad se ponen como locos. Tal es el caso de los eslavófilos, a los que pertenece el señor Gubariov: una gente de lo más estupenda, con esa misma mezcla de desesperación y fogosidad, pero también ellos viven solo pensando en el porvenir. Todo llegará, todo llegará. Pero en realidad nada llega y durante diez siglos Rusia no ha creado nada propio, ni en la administración, ni en la justicia, ni en la ciencia, ni en el arte, ni siquiera en los oficios manuales... Pero espere, tenga un poco de paciencia: todo llegará. No obstante, permítame que le pregunte, ¿por qué llegará todo? Porque nosotros, personas instruidas, no somos más que basura; pero el pueblo... ¡ ah, es un gran pueblo! ¿Ve usted este guardapolvo? Pues todo vendrá de él. Todos los otros ídolos han sido destruidos; pero pongamos, pues, nuestra fe en el guardapolvo. Pero $i y$ si el guardapolvo no cumple con nuestras expectativas? No, eso no sucederá; lea usted a Kojanovski y viva la alegría [...].

—Después de lo que acaba de decir usted —exclamó Litvínov con una sonrisa-, no es necesario que le pregunte a qué partido pertenece y qué opinión tiene de Europa. Pero permítame que le haga una observación. Asegura usted que debemos tomar y aceptar lo que han hecho nuestros hermanos mayores; pero ¿cómo hacerlo sin tener en cuenta las condiciones del clima y del suelo, las particularidades del lugar y de la población? (Turgénev 2003: 52-54)

Encontramos en este fragmento varios culturemas. En primer lugar, la referencia al protopope Avvakum (1620-1682) es un culturema de referente histórico. Avvakum se puso al frente de los que se oponían a las reformas de Nikon (quien pretendía acercar la Iglesia Rusa a la Iglesia Ortodoxa Griega) dando lugar a los llamados viejos creyentes, lo que, entre otras causas, le valió ser ejecutado en la hoguera. En el texto hay, por otro lado, una alusión a la frase «volver a los principios» extraída de la obra de Avvakum Vida del protopote Avvakum y, por tanto, perteneciente a la cultura literaria rusa. Víctor Gallego Ballestero añade 
una nota a pie de página que explica que Avvakum fue un «miembro destacado de la secta de los "viejos creyentes" y autor de una Vida, obra clásica de la literatura rusa». Curiosamente la versión de Eusebio Heras se vale de la técnica traductora de la amplificación y añade una información histórica no presente en el original: «como decía mi respetable amigo el arcipreste Awakum, aquel a quien quemaron en tiempos del czar Teodoro». ${ }^{13}$

El fragmento incluye otra alusión literaria cuando dice «lea usted a Kojanovski» (en realidad, Kojanovskaya), que Gallego Ballestero explica con la siguiente nota: «seudónimo de Nadezhda Stepánovna Sojanski (1825-1884), novelista de tendencias eslavófilas que trataba asuntos de corte popular». En concreto, se refiere a su obra Roy-Feodosi Savvich en calma (1864). Kojanovskaya mostraba en sus obras conmovedoras relaciones patriarcales entre el señor y sus campesinos. Eusebio Heras en su versión traduce como «leed a la señora Koklsanofka» y añade una nota a pie de página explicativa: «novelista que se dedicó a ensalzar los tiempos que pasaron y la santidad ${ }^{14}$ de Rusia».

Encontramos también un juego de palabras cuando dice живут буквой «буки» [zhivut bukvoj «buki»] (literalmente, 'viven con la letra buki'). Por un lado, буки [buki] es el nombre que recibía antiguamente la segunda letra del alfabeto cirílico y también del alfabeto glagolítico, pero, por otro lado, según explica Vladimir Dal' en su Diccionario de la lengua rusa viva, buki expresa algo incierto, un futuro inseguro e impredecible. Gallego Ballestero opta por trasladar este segundo sentido y traduce como «también ellos viven solo pensando en el porvenir» (en este caso se pierde la connotación de que ese futuro es incierto), mientras que el traductor de la edición de Pérez del Hoyo intenta reflejar en cierto modo el juego de palabras traduciendo como «sólo viven de la palabra "porvenir"», solución idéntica a la de Eusebio Heras («sólo viven de la palabra "porvenir"»).

Finalmente, todo el fragmento es una expresión del pensamiento de occidentalistas y eslavófilos. En este caso concreto Potugin expresa un tipo de occidentalismo pesimista y escéptico en lo que se refiere a las capacidades del pueblo ruso para realizar aportes en materia de ciencia y tecnología, si no se llevan a cabo grandes reformas, así como su descontento por el rechazo generalizado a los intelectuales, a la vez que se ensalza al pueblo llano ignorante. Litvínov, por su parte, resalta la importancia de los condicionantes geográficos y climatológicos de Rusia.

\subsection{Culturemas pertenecientes al campo de las normas}

Como apuntaba Bierstedt (1970), en este grupo de contenido cultural se incluirían las leyes, estatutos, reglas, regulaciones, hábitos, tradiciones, costumbres, tabúes, moda, ritos, rituales, ceremonias, convenciones y etiqueta. Es decir, todo aquello relacionado dentro de una cultura con las relaciones e interacción entre los miembros de la sociedad en sus más diversos ámbitos (formas de interactuar las perso-

13. La cursiva es nuestra. Efectivamente Avvakum fue quemado bajo el reinado del zar Fiódor (o Teodoro) III, quien curiosamente murió solo algunos días después.

14. En cursiva en el original. 
nas en diferentes contextos, relación con el estado, actividades cotidianas, expresión pública de la relación entre los hombres y la divinidad, reglamentos por los que se rige cualquier institución de esa cultura, ordenamiento jurídico, etc.).

Cuando alguno de estos fenómenos culturales es específico de una cultura dada (sin menoscabo de lo indicado anteriormente acerca del carácter flexible, abierto y en evolución de los culturemas) nos encontraremos ante un culturema perteneciente al campo de las normas que puede plantear algún problema a la hora de ser trasladado a otra lengua y otra cultura. Este grupo incluiría la cultura social de Nida, Molina Martínez o Newmark, además de las organizaciones, costumbres, actividades y procedimientos y los gestos y hábitos de este último, el modo de vivir de Nord o la conducta de Katan.

En la obra de Turguéniev encontramos numerosos ejemplos de culturemas de este tipo. Comentamos a continuación algunos de ellos muy representantivos. Dentro de este grupo, un tipo de culturemas que se suele analizar con frecuencia es el de cargos, instituciones, realidades socioeconómicas y realidades histórico-políticas propias de esa cultura. Un primer ejemplo en este sentido que vamos a comentar es el de надворный советник [nadvornyj sovetnik] (literalmente 'consejero áulico') que encontramos en el capítulo V de Humo referido al personaje de Potugin. Se trata de un cargo del funcionariado civil histórico en Rusia. Pedro I estableció un sistema de funcionariado con 14 rangos (luego reducidos a 12) divididos en civiles, militares y palatinos (es lo que se conoce como Tabla de rangos). Cada rango tenía su propio tratamiento. Se ascendía por años trabajados (3-4 años) o por recibir determinadas condecoraciones. Se les exigía, además, como requisito una determinada formación. Con el establecimiento de este sistema, Pedro I lo que pretendía es ir restando poder a la nobleza de sangre en favor de esta nobleza de mérito. El servilismo hacia los superiores fue ironizado por muchos escritores, como por ejemplo Antón Chéjov en El camaleón. Por la época en la que Turguéniev escribió Humo el consejero áulico era un funcionario de rango 7, es decir, ya de cierta importancia, aunque numéricamente se encontrara en la mitad de la tabla (recibía, por ejemplo, automáticamente la dignidad de nobleza personal —hasta 1845 incluso hereditaria), su forma de tratamiento era su excelencia y equivalía por rango en el ejército al podpolkovnik ('teniente coronel') y en la armada al capitán de segundo rango. Las personas que ostentaban este rango podían desempeñar funciones de dirección de departamentos ministeriales o de gobernación en las provincias (o gobiernos, en ruso gubernija) del Imperio Ruso. Saber esto permite al lector conocer en detalle al personaje de Potugin y las connotaciones que tiene.

A continuación, deberíamos aclarar el grado de afinidad de este culturema (punto 4 del procedimiento que indicábamos más arriba) con respecto al receptor, en nuestro caso el lector español. Consideramos que en este caso el grado de afinidad es medio: por un lado, ciertamente no existe un sistema plenamente equivalente en España, pero por otro lado sí que existe, evidentemente, una jerarquización en los cargos públicos de servicio al Estado.

Por su relevancia semiótica este culturema es de grado medio. No supone una de las piezas centrales para entender la obra, pero si es necesario para entender la caracterización del personaje de Potugin. 
Por último, pasamos a comentar las soluciones traductológicas de cada traductor. Para ello reproducimos primero el párrafo original en que aparece y después la traducción de Eusebio Heras:

- Г-н Губарев, у которого я имел удовольствие вас видеть сегодня, — начал он,- меня вам не отрекомендовал; так уж, если вы позволите, я сам себя рекомендую: Потугин, отставной надворный советник, служил в министерстве финансов, в Санкт-Петербурге. Надеюсь, что вы не найдете странным... я вообще не имею привычки так внезапно знакомиться... но с вами...

—El señor Gubaref, en cuya casa me habéis visto — comenzó diciendo el desconocido-, en cuya casa tuve el gusto de veros, no os ha dicho mi nombre; si me lo permitís, lo haré yo mismo. Me llamo Potughin, y soy consejero de corte retirado; serví en el Ministerio de Hacienda de San Petersburgo. Espero que no os sorprenda lo que digo... No acostumbro a presentarme de este modo a las personas, mas con vos... (Turguenef s.a.: 39)

El traductor anónimo de 100 clásicos universales publicada por Pérez del Hoyo también traduce como «consejero de corte», y V. Gallego Ballestero como «consejero de la corte».

Dentro de este grupo de culturemas también estarían las formas de tratamiento. En el fragmento de la conversación entre Litvínov y Potugin de Humo reproducido en el apartado 3.2 encontramos милостивый государь [milostivyj gosudar'] (muy literalmente se podría traducir como 'benevolente señor'; el adjetivo милостивый procede del sustantivo милость, usado también como forma de tratamiento, ваша милость $\approx$ 'usía' о 'vuesarced'). Se trata de una manera bastante formal de dirigirse a otro individuo que por su dignidad o cargo no requiera otras formas de tratamiento (высокоблагородие, высокопревосходительство, высочество, величество, ехсеlencia, ilustrísimo, vиесепcia, alteza, etc.) ampliamente utilizado en el s. XIX. Gallego Ballestero lo traduce como «querido amigo», solución válida dentro de un skopo de acercarse al lector actual sin desvirtuar el tono del original.

Por su parte, la palabra государь [gosudar'] nos da pie a comentar otra particularidad de la lengua rusa de aquella época y de las formas de tratamiento como forma de interactuar los individuos en sociedad. Nos referimos a la partícula postclítica $-c$ (denominada en ruso словоерс о словоерик [slovoers o slovoerik]), usada en el s. XIX como forma de respeto hacia el interlocutor y que procedía de la apócope de la palabra sudar ('señor', 'caballero'). Era muy frecuente tras palabras como sí o no, como vemos en este pasaje pronunciado por Pável Petróvich en Padres e hijos:

Я очень хорошо знаю, например, что вы изволите находить смешными мои привычки, мой туалет, мою опрятность наконец, но это все проистекает из чувства самоуважения, из чувства долга, да-с, да-с, долга. (Тургенев 19782014 [1981]: 48) 
Esta forma es difícil de trasladar a español y en ocasiones la mejor opción es omitirla, como hacen el traductor de la versión de Revista internacional, R. Cansinos Assens y B. Martinova. R. Cañete Fuillerat, por su parte, opta por traducir como «sí, sí, señor mío», J. Eduardo Zúñiga como «sí señor, sí señor» y J. Fernández-Valdés como «sí, señor, sí». Reproducimos la traducción al español del pasaje en la versión de J. Fernández-Valdés:

Sé muy bien que usted se digna considerar ridículas mis costumbres, mi modo de vestir, mi pulcritud, en definitiva. Pero todo esto deriva del respeto que siento por mí mismo, de mi sentimiento del deber; sí, señor, sí: del deber. (Turguénev 2018: 78-79)

Otros culturemas de este segundo gran grupo se enmarcarían en el contexto histórico en que se sitúa. Las reformas del zar Alejandro II, sobre todo las encaminadas a abolir la servidumbre (1861), dieron lugar a una serie de posturas y reacciones muy diversas. Gran parte de la alta nobleza estaba en contra, pero otra parte aceptaron y apoyaron dichas reformas porque consideraban bochornoso el régimen de servidumbre, y en general veían necesario que Rusia se fuera transformando y progresando.

Conocer estos cambios políticos (con su consiguiente reflejo en las relaciones sociales) es necesario para aprehender la obra de Turguéniev en toda su magnitud. Es lo que podemos apreciar en el siguiente pasaje de Padres e hijos, que vemos en el original i en la traducción de R. Cansinos Assens:

У дверей, над криво прибитою визитною карточкой, виднелась ручка колокольчика, и в передней встретила пришедших какая-то не то служанка, не то компаньонка в чепце - явные признаки прогрессивных стремлений хозяйки. (Тургенев 1978-2014 [1981]: 62)

En la puerta, por encima de una tarjeta de visita, fijada de través, asomaba la manecilla del timbre, y en el vestíbulo salía a recibir a los visitantes una mujer indefinida, que no era ni una vulgar criada ni una doncella con cofia..., indicios manifiestos de las ideas progresivas de su señora. (Turgueniev 1951: 418-419)

El hecho de que la señorita que salga a recibirlos ataviada con una cofia vaya vestida de tal manera que no queda claro si se trata de una criada en su versión más tradicional y antigua en la sociedad rusa (служанка sluzhanka) o de una dama de compañía, figura más afín a lo que tenía la nobleza occidental de la época, donde ya no existía la servidumbre (de hecho, la misma palabra компаньонка [kompanionka] procede etimológicamente del francés compagnon 'compañero' y supone el equivalente de la figura francesa de la dame de compagnie, una innovación con respecto a las criadas tradicionales (su referencia más antigua en el Corpus Nacional de la Lengua Rusa (vid. Grishina y Savchuk 20032020) es de 1834, en la obra de N. A. Polevoy Emma, y la usa ya Turguéniev apenas en la década siguiente, mientras que la palabra sluzhanka es muy anterior). Supone para el autor un signo de las tendencias progresistas de la señora de 
la casa, ya que esta no querría que sus criados quedaran claramente marcados y reconocibles como tales.

La idea que transmite el pasaje se mantiene en todos los traductores, pero es interesante especificar la variante que usa cada uno: señorita de compañía (Revista Internacional, J. E. Zúñiga y R. Cañete Fuillerat), doncella (R. Cansinos Assens) y dama de compañía (B. Martinova).

\subsection{Culturemas pertenecientes al campo de la cultura material}

El último gran grupo por contenido cultural que vamos a analizar es el referido a todas aquellas realidades físicas (cultura material, frente a los dos grupos anteriores que eran cultura no-material) que caracterizan una sociedad.

R. Bierstedt (1970) tiene en mente al hablar de este grupo de todos aquellos objetos que una sociedad conoce y usa (máquinas, herramientas, utensilios, edificios, carreteras, puentes, artefactos, obras de arte, ropa, etc.). Por lo que respecta a la traductología y a los culturemas como objeto de estudio, nosotros vamos a incluir y analizar en este grupo toda realidad física que determina una cultura, por lo que también tenemos en cuenta aspectos como clima, accidentes geográficos, fenómenos naturales y otros factores de la naturaleza.

Este grupo abarcaría, por tanto, la ecología (medio natural en Molina Martínez) y la cultura material de Nida y Newmark, el entorno de Katan y, en parte (la referida a realidades físicas), el patrimonio cultural de Nord y Molina Martínez.

Algunos de los culturemas rusos más famosos de este grupo los encontramos ampliamente en las obras de Turguéniev: isbá (típica casa rusa construida con troncos de árboles), samovar (recipiente metálico para hervir agua y preparar té típicamente ruso), la troika rusa (tipo de carruaje tirado por tres caballos), armiak (tipo de abrigo largo), etc. No obstante, el mundo material de la cultura rusa es inmenso y encontraremos en la literatura rusa numerosas referencias a él.

Las obras de Turguéniev están repletas de culturemas de este tipo característicos de la Rusia del XIX. Nos vamos a valer del siguiente fragmento de Rudin, donde aparecen varios culturemas materiales, para comentarlos desde el punto de vista traductológico:

Александра Павловна вошла в избу. В ней было и тесно, и душно, и дымно... Кто-то закопошился и застонал на лежанке. Александра Павловна оглянулась и увидела в полумраке желтую и сморщенную голову старушки, повязанной клетчатым платком. Покрытая по самую грудь тяжелым армяком, она дышала с трудом, слабо разводя худыми руками. (Тургенев 1978-2014 [1980]: 199-200)

Lezhanka (лежанка) es vocablo ruso que hace referencia al poyo, normalmente de piedra o ladrillo, bajo el cual se ubicaba una estufa para dar calor. Era un lugar donde se pasaba bastante tiempo realizando labores caseras (como bordar) mientras se conversaba. P. V. Annenkov escribe en una carta de 1875 (vid. Annenkov 2005: 24) dirigida precisamente a I. S. Turguéniev, hablando del cua- 
dro La aldea de Malinovka de Jean-Louis-Ernest Meissonier: «От нее веет чистой, целомудренной девической спаленкой и рабочей комнаткой, с анализом, который в них помещается обыкновенно, как кот на лежанке» ('Se respira en él el ambiente del dormitorio y del cuarto de trabajo de una muchacha limpia y casta, con un tratamiento de lo que suele haber en ellos, como un gato sobre una lezhanka'). Suele transmitir connotación de calor, comodidad, lugar acogedor.

Se trata de un culturema sin un equivalente directo en la cultura española, al menos de manera generalizada. Su relevancia semiótica en la traducción de Rudin es baja, pues no es un elemento esencial para entender el desarrollo de la novela. El conjunto de culturemas de este tipo, no obstante, ayudan a describir y transmitir cómo era la vida en la Rusia de aquella época y de ese ambiente rural. La traducción anónima de 1893 traslada al español el pasaje del siguiente modo:

Alexandra Pavlovna entró en la choza, estrecha, llena de humo, con un calor sofocante... Alguien se agitaba y gemía encima del fogón. Alexandra Pavlovna echó una mirada en torno suyo, y distinguió entre la semioscuridad la cara amarilla y arrugada de una vieja, con la cabeza envuelta en un pañuelo á cuadros. Cubríala hasta el pecho un pesado caftán. Respiraba con esfuerzo y removía débilmente las enflaquecidas manos. (Turguenef 1893: 5-6)

La palabra fogón en español se refiere al lugar para cocinar, pero en el imaginario español no se encuentra la posibilidad de tumbarse sobre él, por lo que este culturema material suena extraño en la traducción. El cuadro descrito aparece en la traducción de Rosa María Turuguet del siguiente modo:

Alejandra Paulovna entró en la cabaña. En su interior apenas uno podía moverse; las paredes estaban ennegrecidas por el humo, el calor era sofocante. Alguien se movía y gemía encima de la estufa. Alejandra Paulovna echó una mirada a su alrededor y distinguió en la penumbra el rostro amarillo y arrugado de una vieja, cuya cabeza estaba envuelta con un pañuelo a cuadros. Un pesado caftán la cubría hasta el pecho; respiraba con dificultad y no cesaba de mover débilmente sus enflaquecidas manos. (Turguéniev 1942: 10)

La traductora opta por añadir una nota a pie de página: «Los campesinos pobres duermen habitualmente sobre sus estufas». Como hemos mencionado anteriormente en una nota, también el traductor anónimo de Revista literaria traduce lezhanka como estufa. Rafael Cansinos Assens traduce el fragmento del siguiente modo:

Alejandra Pavlovna entró en la isba. Reinaban en ella oscuridad, ahogo y bruma... Alguien se revolvía y quejaba en un camastro. Miró Aleksandra Pavlovna y vislumbró en aquella penumbra la amarillenta y arrugada faz de una anciana, con la cabeza envuelta en un pañuelo a cuadros. Cubierta hasta el pecho por pesado corpiño, alentaba con dificultad, moviendo débilmente las manos. (Turgueniev 1951: 4) 
El traductor realiza una traducción de la palabra que no transmite del todo el objeto real. Tampoco añade ninguna nota ni aclaración, por lo que el culturema como tal se pierde. Aníbal Leal, en su versión, opta por transliterar («alguien se movió y gimió sobre la liejaneka») y añadir la siguiente nota a pie de página: «chimenea baja usada como cama». Finalmente, la versión de Jesús García Gabaldón usa también como traducción camastro y se presenta así:

Alexandra Pávlovna entró en la isba. Dentro se estaba muy estrecho, en un ambiente sofocante y ahumado. Alguien se revolvía y gemía en un camastro. Alexandra Pávlovna echó un vistazo y en la penumbra vislumbró la cabeza amarillenta y arrugada de la anciana, envuelta en un pañuelo a cuadros. Cubierta hasta el pecho por un tabardo, respiraba con dificultad separando débilmente sus manos enjutas. (Turguéniev 1997: 10)

De este fragmento podemos comentar también el culturema material armiak (армяк), palabra de origen túrcico que se define como 'ropa de abrigo masculina campesina, hecha de tela gruesa en forma de bata o caftán recto con capucha larga' y que los diccionarios traducen como 'tabardo'. En el fragmento vemos que es una anciana quien lo lleva puesto. Turuguet opta por traducirlo mediante una palabra que transmite aproximadamente la imagen del original, pero que es comprensible para el lector español medio (caftán), mientras que Cansinos Assens lo traduce como corpiño, lo que no es exacto y puede dar una idea equivocada. J. García Gabaldón se vale del citado vocablo tabardo.

Este culturema, por cierto, ya nos había aparecido en el fragmento de Humo citado en el apartado 3.1.; en ese caso el traductor, Víctor Gallego Ballestero, lo había traducido como guardapolvo, mientras que el traductor anónimo de la edición de Pérez del Hoyo opta por transliterar (armiak) y añadir la nota a pie de página «así se llama una parte muy principal del traje de los aldeanos». Eusebio Heras, por su parte, también translitera como armiak, pero añade una nota a pie de página: «prenda esencial del traje del aldeano ruso».

Podríamos añadir finalmente en el fragmento citado el caso de izba (избa), casa hecha de troncos de madera característica de la Rusia rural. Es un vocablo quizá más conocido para el lector español, traducido, no obstante, por la versión de 1893 como choza y como cabaña por Turuguet, mientras que Cansinos Assens, Aníbal Leal y García Gabaldón optan por transliterar (isba), nuevamente sin añadir ninguna aclaración.

Las particularidades de la naturaleza, la flora y la fauna de cada cultura pueden crear culturemas conocidos para los miembros de dicha cultura que hagan referencias a asociaciones de ideas o connotaciones desconocidas para individuos de otra cultura ajena.Analizamos un primer caso presente en la novela de Rudin que nos ha parecido curioso. Veamos en primer lugar el pasaje:

— [...] Отчего ты не мог ужиться в гимназии, отчего ты — странный человек! - с какими бы помыслами ни начинал дело, всякий раз непременно кончал его тем, что жертвовал своими личными выгодами, не пускал корней в недобрую почву, как она жирна ни была? 
— Я родился перекати-полем, — продолжал Рудин с унылой усмешкой. — Я не могу остановиться. (Тургенев 1978-2014 [1980]: 320)

En este diálogo, cuando Lezhnev le pregunta sorprendido a Rudin por qué nunca echó raíces en ningún sitio, este le responde usando una planta como símil de persona que siempre necesita ir desplazándose de un lado para otro. Se trata de lo que en ruso se denomina перекати-поле (perekati-pole), de perekatit' 'rodar' y pole 'campo', y en español estepicursor, término que hace referencia a varias especies de plantas que se desplazan rodando (formando a veces grandes esferas). $\mathrm{Su}$ grado de relevancia semiótica según el cuadro que hemos introducido sería baja, pues realmente no es un elemento esencial para entender la novela, pero sí que nos parece un delicioso ejemplo de culturema de este primer grupo estudiado. Aunque el grado de afinidad con la cultura de llegada es bastante elevado, pues ese tipo de plantas también se conocen en el mundo hispánico, nos ha parecido interesante como culturema, pues se aprecia una diferencia en las alusiones y connotaciones que tiene para la cultura española y rusa. Mientras que para el lector español suele ser símbolo de lugar desierto y desangelado (piénsese en las películas del Oeste, por ejemplo), en Rusia (aun cuando hoy en día también se asocia como algo característico de las películas del Oeste) siempre se ha usado como símbolo de persona que vaga de un lugar a otro sin echar raíces en ningún sitio. Es decir, se trata de un culturema fácilmente reconocible por un lector español (por el contexto inmediatamente entenderá que hace una comparación entre su modo de vivir errante y este tipo de plantas que van rodando de un sitio a otro), pero no fijado como tal en la cultura española, como sí lo está en la rusa.

A pesar de que en la lengua española existen muchas palabras para referirse a este tipo de plantas, tanto la genérica de estepicursor como otras más dialectales del tipo rodamundos, sorrasca, churumico, calamino, boja, salicón, salicor, salicornio, alicornio o incluso cardo ruso, entre otras muchas. El traductor de La España Moderna optó por transliterar dejando el pasaje en español del siguiente modo:

- $[\ldots]$ ¿Por qué no has podido vivir en el Instituto? ¿Por qué, hombre extraño, cuando emprendías un negocio lo abandonabas, sacrificando tus propios intereses y sin echar raíces en ninguna tierra, por fértil que fuera?

-Yo soy perecatipol de nacimiento — dijo Rudín, ${ }^{15}$ con humilde sonrisa. —No puedo detenerme. (Turguenef 1893: 103)

Y añade una nota a pie de página con la siguiente aclaración: «Planta que crece en las estepas y que echa raíces allí donde la va llevando el viento», quizá no del todo acertada como explicación del culturema, pues resalta el hecho de cómo echa raíces, cuando en el texto se usa precisamente para enfatizar el hecho de errar de un lado para otro sin asentarse en ninguno.

15. El traductor de La España Moderna, María Rosa Turuguet y el traductor de Revista literaria acentúan Rudín (con acento en la $i$ ). Fenómeno curiosamente frecuente entre los hispanohablantes, que a menudo cambian de lugar el acento de muchas palabras rusas. Nosotros mantendremos la grafía (y la ortografía) empleada en el original de cada edición. 
María Rosa Turuguet (y la traducción de Revista literaria de 1954) también optó por transliterar y vemos que su traducción debió de beber bastante de la de 1893:

- $[\ldots]$ ¿Por qué no has podido vivir en el instituto? ¿Por qué, hombre raro, cuando emprendías un negocio lo abandonabas, sacrificando tus propios intereses y sin echar raíces en ninguna tierra, por fértil que fuera?

-Yo soy perecati-pole de nacimiento — respondió Rudín, con humilde sonrisa-. No puedo detenerme en parte alguna. (Turguéniev 1942: 214)

Y añade la siguiente nota a pie de página semejante al aparecido en la traducción de 1893 (lo que, entre otras cosas, atestigua la influencia entre ambas versiones): «Planta que nace en las estepas y cuya naturaleza es echar raíces allí donde la lleva el viento», aclaración de la que podríamos hacer el mismo comentario que acabamos de realizar al hablar de la versión de 1893. Rafael Cansinos Assens, por su parte, traduce el pasaje en su versión del siguiente modo:

- $[\ldots]$ ¿Por qué no pudiste acomodarte al gimnasio, por qué..., hombre extraño?... Siempre que empezaste una cosa con buena intención, terminaste sacrificando tus intereses personales y sin echar raíces en una tierra mala, por crasa que fuere.

-Yo he nacido para volar — dijo Rudin con triste sonrisa-. Y no puedo detenerme. (Turgueniev 1951: 144)

Como podemos apreciar, ha realizado una adaptación del culturema valiéndose de una traducción más libre, pero conservando la idea que pretendía transmitir el original. Por otra parte, en la versión de Aníbal Leal leemos:

- [...] Y por qué no pudiste continuar trabajando en tu liceo... iqué hombre extraño! ¿Por qué sacrificaste siempre tu provecho personal, cualesquiera fuesen tus proyectos? EN definitiva, ¿por qué jamás arraigaste aunque fuese en una tierra refractaria, si tú sabías que podías llegar a ser fecunda?

-Nací para rodar de un lugar a otro — respondió Rudin con una sonrisa fatigada-. No puedo detenerme. (Turgueniev 1981: 186)

También este traductor sacrifica la imagen del culturema y la fuerza literaria del mismo en pos de trasladar más claramente al lector el sentido. Jesús García Gabaldón, finalmente, opta por una traducción mucho más libre y que se aleja del culturema empleado por el original. Su versión del pasaje suena así:

- [...] ¿Por qué no pudiste acostumbrarte a la vida del Instituto? ¿Por qué tú, hombre extraño, cualesquiera que fueran tus propósitos al empezar una empresa, la acababas infaliblemente sacrificando tus intereses personales, y no echabas raíces en una tierra mala, por muy fértil que fuera?

-Nací siendo un villano - replicó Rudin con triste sonrisa- No puedo pararme. (Turguéniev 1997: 162) 
Como podemos observar, en esta última traducción además de no reflejarse el culturema tal como aparece en el original, no queda clara la conexión entre ser un "villano" y no poder detenerse.

\section{Conclusiones}

Los culturema son unidades semióticas culturológicas y traductológicas que expresan especificidades culturales de una sociedad dada y que, por tanto, pueden provocar dificultades a la hora de trasladarlos a otra lengua y otra cultura diferente.

Por su referente, los culturemas han sido clasificados en diversos grupos dependiendo del autor, pero en última instancia podrían distinguirse (al igual que hace Bierstedt (1970) con el contenido de la cultura) en tres grandes grupos: los que surgen del pensamiento humano, los que surgen de la interacción humana y los que surgen de las realidades físicas.

En el presente artículo hemos desarrollado un método de análisis culturo-traductológico de culturemas que incluye entre sus aspectos o fases de aplicación: 1) la localización de culturemas en un texto dado; 2) la adscripción a una de las categorías por tipo de referente (ideas, normas y cultura material, en la clasificación que hemos seguido, pero podría ser también en base a los cinco grupos de problemas de traducción que estableciera Nida (1945) y las subsiguientes variaciones en autores posteriores); 3) la descripción del culturema en sus aspectos más problemáticos a la hora de ser trasladado a otra lengua (especificidades de tipo histórico, social, lingüístico, etc.); 4) la determinación de afinidad con la cultura de llegada (que podrá estar determinada por la existencia de un equivalente cercano en la cultura de llegada o por un mayor o menor conocimiento de ese culturema entre los hablantes de la cultura de llegada); 5) la determinación de su relevancia semiótica en la traducción (puede ser alta, media o baja en función de la importancia que tenga ese culturema dado para la comprensión del texto original); 6) la descripción y análisis de las soluciones traductológicas teniendo en cuenta el principio de equivalencia dinámica y otros principios traductológicos como son el skopos, el método traductor, las estrategias traductoras por las que ha optado el traductor, etc. El estudio de las soluciones traductológicas empleadas en la traducción de culturemas se convierte, por tanto, en una suerte de exégesis culturológica, lingüística y literaria.

Según el método de análisis culturo-traductológico de culturemas, por tanto, para analizar las soluciones traductoras escogidas por un traductor habrá que tener en cuenta y analizar otros aspectos como el pensamiento y visión del mundo del autor, características históricas y sociales del autor y del lugar y tiempo donde transcurre la acción de la obra, particularidades lingüísticas de la lengua de partida, etc.

En nuestro artículo hemos aplicado este método de análisis en la traducción al español de obras de Iván Turguéniev, por lo que hemos incluido primeramente un apartado dedicado al pensamiento, obra y circunstancias históricas que rodearon al escritor ruso. El análisis se ha llevado a cabo en la parte práctica en tres suba- 
partados distintos en función del referente del culturema: ideas, normas y cultura material.

De este modo podemos entender que un vocablo como Europa pueda ser considerado como un culturema complejo cuando analizamos el debate filosófico entre eslavófilos y occidentalistas que ocupó buena parte del siglo XIX ruso. Es lo que hemos realizado en el primer subapartado de culturemas, junto al análisis de muchos otros de tipo lingüístico (juegos de palabras, alusiones humorísticas) e histórico (personajes históricos del mundo del pensamiento y la literatura). El trabajo del traductor debe ser, si cabe, más meticuloso a la hora de identificar y trasladar los culturemas de este grupo, lo que no siempre es fácil, a menos que se recurra a técnicas traductológicas de amplificación, compensación, descripción, modulación o incluso adaptación, además del uso de notas aclaratorias. En el caso de culturemas lingüísticos la dificultad para el traductor no será ya solo de fondo, sino de forma.

En el segundo subapartado, hemos analizado culturemas referidos a cargos públicos, instituciones, formas de tratamiento y relaciones interpersonales. El método seguido nos permite aprehender estos culturemas con mayor profundidad y conocer todas las implicaciones y alusiones que producían en el lector del original. Este tipo de culturemas con frecuencia tienen una relevancia semiótica media o elevada, sobre todo en el caso de Turguéniev. Un problema difícil de solucionar desde el punto de vista traductológico que presentan estos culturemas es que, debido a la influencia occidentalizante generalizada, sobre todo a partir de la cultura francesa y parcialmente de Inglaterra o Alemania, el referente del culturema puede existir tanto en la cultura de partida como en la de llegada, pero que las connotaciones implícitas difieran de una cultura a otra y no se perciba por parte del lector.

En el tercer subapartado, el de los culturemas surgidos a partir de realidades físicas específicas de la cultura rusa, más allá de realizar una descripción del objeto, hemos pretendido analizar las connotaciones que dichas realidades físicas podían producir en el lector del original. En general se observa que, como en todas las culturas suelen haber objetos parecidos o que vagamente se asemejan en forma o función a los de los culturemas de este grupo, los traductores se valen de esos equivalentes cercanos, cayendo a veces en una deformación del cuadro retratado en el original o, por supuesto, del color local. En el caso de realidades referidas a la naturaleza (la Ecología de Nida) con frecuencia los traductores transmiten el sentido denotativo que hay tras estos culturemas, aunque a veces a costa de sacrificar el colorido y la vitalidad que transmite el culturema en el original.

El análisis culturo-traductológico de culturemas permite al investigador y al lector aprehender dichos culturemas de una manera más amplia y profunda, entender y valorar las distintas soluciones de un traductor en base al objetivo de su traducción, y complementar la información y connotaciones que dichos culturemas transmiten y que en una traducción a veces sería imposible de trasladar sin alterar el efecto literario o el ritmo de lectura de la obra. 


\section{Ediciones y traducciones de obras de Turguéniev empleadas}

Turgenev, Ivan Sergeevič [Тургенев, Иван Сергеевич] (1978-2014). Polnoe sobranie sočinenij i pisem: v 30 t. [Полное собрание сочинений и писем: $B$ 30 m.] / АН СССР, ИРЛИ (Пушкинский Дом); [редкол.: М.П. Алексеев (гл. ред.) и др.]. Moscú: Nauka. <https://rvb.ru/turgenev/toc.htm>.

Turgenev, Ivan Sergeevič [Тургенев, Иван Сергеевич] (2001). Otcy i deti. Rasskazy. Povesti. Stihotvorenija v proze [Отиы и дети. Рассказы. Повести. Стихотворения в прозе]. Moscú: Olimp; AST.

Turgenev, Ivan Sergeevič [Тургенев, Иван Сергеевич] (2009). Rudin [Рудин]. San Petersburgo: Azbuka-klassika.

Turguenef ${ }^{16}$ (1893). Demetrio Rudín. Traducción anónima. La España Moderna. Revista Ibero-Americana, LVII, 5-106.

Turguenef, Iván (s.a.). Humo. Traducción de E[usebio] Heras [Hernández]. Barcelona: Maucci.

Turguéniev, Iván (1942). Demetrio Rudín. Traducción de María Rosa Turuguet. Barcelona: Nausica.

Turgueniev, Iván S. (1951). Obras escogidas (Rudin, Nido de nobles, Padres e hijos, Aguas de primavera, Memorias de un cazador, Un mes en la aldea, Poemas en prosa). Traducción de Rafael Cansinos Assens. Madrid: Aguilar.

Turgueniev, Iván (1954). Demetrio Rudín. Traducción anónima. Revista literaria. Novelas y cuentos, 1.189, 1 (513)-60 (572).

Turgueniev, Iván (1969). Humo. Colección 100 clásicos universales. Traducción anónima. Madrid: Pérez del Hoyo.

Turgueniev, Iván (1981). Dimitri Rudin. Traducción de Aníbal Leal. Buenos Aires: Javier Vergara Editor.

Turguéniev, Iván (1997). Rudin. Traducción de Jesús García Gabaldón. Barcelona: Alba.

Turguénev, Iván Serguéievich (2003). Humo. Traducción de Víctor Gallego Ballestero. Barcelona: Alba.

Turguénev, Iván Serguéievich (2018). Padres e hijos ( $2^{\mathrm{a}}$ ed.). Traducción de Joaquín Fernández-Valdés. Barcelona: Alba.

\section{Referencias bibliográficas}

Annenkov, Pavel Vasil'evič [Анненков, Павел Васильевич] (2005). Pis'ma k I. S. Turgenevu. Kn. 2: 1875-1883 [Письма к И.С. Тургеневу. Кн. 2: 1875-1883] / Izd. N. N. Mostovskaja, N. G. Žekulin. San Petersburgo: Nauka.

Bierstedt, Robert (1970). The social order (3rd ed.). Nueva York: McGraw-Hill.

CATford, John Cunnison (1965). A linguistic Theory of Translation. An Essay in Applied Linguistics. Londres: Oxford University Press, [Trad. a español de F. Rivera: Una teoría lingüística de la traducción. Ensayo de lingüística aplicada. Caracas: Universidad Central de Venezuela, 1970).

16. En la presente bibliografía mantenemos la forma del nombre y el apellido empleada en cada edición. 
Coseriu, Eugen (1977). «Lo erróneo y lo acertado en la teoría de la traducción». En: El hombre y su lenguaje. Madrid: Gredos, p. 214-239.

DAL', Vladimir Ivanovič [Даль, Владимир Иванович] (1863-1866 [2008-2017]). Tolkovyj slovar' živago velikoruskago jazyka [Толковый словарь живаго великорускаго языка]. Moscú: A. Semën. <http://slovardalja.net>.

Grishina, Elena; SAvchuK, Svetlana [Гришина, Елена; Савчук, Светлана] (руководители проекта) (2003-2020). Nacional'nyj Korpus Russkogo Jazyka [Наџиональный Корпус Русского Языка]. <www.ruscorpora.ru>.

Hurtado Albir, Amparo (2004 [2001]). Traducción y Traductología. Introducción a la Traductología. Madrid: Cátedra.

Jaskot, Maciej Paweł; Ganoshenko, Iurii (2015). «Culturemes and Non-Equivalent Lexis in Dictionaries». Cognitive Studies, 15, p. 115-124.

Koсвек, Alenka (2012). «An integrated model for translating legal texts». Vertimo Studijos, 5, p. 64-75. <http://www.vertimostudijos.flf.vu.lt/wp-content/uploads/2015/01/ Vertimo_studijos_5.65-76.pdf>.

LuQue Durán, Juan de Dios (2001). Aspectos universales y particulares del léxico de las lenguas del mundo. Serie Granada Lingvistica. Granada: Granada Lingvistica.

LuQue NADAL, Lucía (2009). «Los culturemas: ¿unidades lingüísticas, ideológicas o culturales?» Language Design, 11, p. 93-120. <http://elies.rediris.es/Language_Design/ LD11/LD11-05-Lucia.pdf>.

Maslova, Valentina Avraamovna [Маслова, Валентина Авраамовна] (2004). Lingvokul'turologija [Лингвокульурология] (2-e izd.). Moscú: Academia.

Molina Martínez, Lucía (2001). Análisis descriptivo de la traducción de los culturemas árabe-español [tesis doctoral]. Barcelona: Universitat Autònoma de Barcelona $<$ https://www.tdx.cat/handle/10803/5263>.

- (2006). El otoño del pingüino: análisis descriptivo de la traducción de los culturemas. Castellón de la Plana: Publicaciones de la Universitat Jaume I.

Newmark, Peter (1988). A textbook of Translation. Londres: Prentice Hall.

Nicolae, Adina Oana (2015). «Multicultural dialogue: Translating culturemes». En: Discourse as a Form of Multiculturalism in Literature and Communication (p. 215-222). Tîrgu-Mureș: Archipelag XXI Press.

NidA, Eugene Albert (1945). «Linguistics and Ethnology in Translation-Problems». Word, 1 (2), p. 194-208.

- (1959). «Principles of Translation as exemplified by Bible Translating». En: R. A. Brower (ed.). On translation (p. 11-31). Cambridge: Harvard University Press.

- (1975). Exploring semantic structures. München: Wilhelm Fink Verlag.

PAmies Bertrán, Antonio (2013). De lingüística, traducción y léxico-fraseología. Homenaje a Juan de Dios Luque Durán. Granada: Comares.

Poyatos, Fernando (1976). Man Beyond Words: Theory and Methodology of Nonverbal Communication. Nueva York: New York State English Council. (New York State English Council Monographs; 15)

ReISs, Katharina; VermeER, Hans Joseph (1996). Fundamentos para una teoría funcional de la traducción. Madrid: Akal.

Soto Almela, Jorge (2013). «La traducción de culturemas en el ámbito del patrimonio cultural: análisis de folletos turísticos de la región de Murcia». Tonos Digital. Revista de Estudios Filológicos, 24. <https://www.um.es/tonosdigital/znum24/secciones/tritonos-3-culturemas.htm>

Vercher García, Enrique Javier (2008). La transmisión al ruso de especificidades culturales españolas en las traducciones de «Don Quijote» de K. P. Masal'skij y N. M. 
Ljubimov [tesis doctoral]. Bolonia: Università di Bologna <http://amsdottorato.unibo. it/1028/>. [Revisada y publicada como: Vercher García, E. J. (2011). Don Quijote entre las nieves. Alcalá de Henares: Centro de Estudios Cervantinos.]

Vinay, Jean-Paul; Darbelnet, Jean (1958). Stylistique comparée du français et de l'anglais. Méthode de traduction. París: Didier. 